DOI 10.14746/ssp.2021.3.5

\author{
Artur Marcin LOREK \\ Mieszko I College of Education and Administration in Poznan \\ ORCID ID: 0000-0002-3468-7037 \\ a.lorek@wykladowcy.wspia.pl
}

\title{
A System for Securing the Durability and Effectiveness of the Three Seas Initiative
}

\begin{abstract}
Abstract The purpose of this article is to evaluate the security system for the durability and effectiveness of the Three Seas Initiative as an informal union of Central European countries. The author diagnoses a set of elements that constitute potential 'fuses' for implementing the goals set by 3 SI: embedding the Initiative's priorities within strategic EU programmes, informalization and decentralization of cooperation, and development of mutual business and economic cooperation. The analysis of the security system has been embedded in the context of contemporary challenges faced by Europe. In order to verify the problem of security mechanisms, desk research was carried out, which consisted of a system (political) analysis and elements of strategic analysis. The result of the research work was to determine the mutual interaction and conditioning of the individual pillars of the durability and effectiveness of 3SI. Thus, evidence was carried out for the legitimacy of recognizing the three previously defined aspects as crucial for the effective operation of the Three Seas Initiative.
\end{abstract}

Key words: Three Seas Initiative, durability, effectiveness, Central Europe, European Union

\section{Introduction - genesis and diagnosis of a research problem, potential solutions, and research outline}

The statement that the political (or even political and social) break-
throughs taking place in the Visegrad Group (V4) countries have resulted in radical changes in the policy vectors of these countries is one of the conclusions of the earlier research carried out by the author of this article (Lorek, 2020). In this context, the future of the Three Seas Initiative (3SI) as a broad forum of Central European countries, whose core is the V4, may arouse uncertainty and anxiety. Will possible changes in a public mood not translate into a decrease in political interest in the 3SI project?

The risk may mitigate in several potential ways; however, it is worth extending that problem by asking the following question: How to ensure 
the durability and effectiveness of 3SI goals achievement? Is there a formal system to secure project continuity? If so, how does it work?

Durability should be understood as ensuring the possibility of uninterrupted pursuit of the goals set by the Initiative. In this context, the project's resistance to possible political changes or the influence of external factors is also included. The concept of effectiveness, in turn, should be understood as the ability to achieve goals in the form in which they appeared at the stage of conceptualization and design.

In the author's opinion, the Initiative's chances of success may be seen in obtaining tires in the EU programmes by strategic projects for 3SI, such as the TEN-T network. ${ }^{1}$ Then the goals of Central Europe will be secured in the long term. The second issue that may immunize the Three Seas against the threat is decentralized an informal character. The initiative takes the form of a platform of cooperation between heads of state without the main leader (although at the beginning of 2015, the president of Croatia, Kolinda Grabar-Kitarović, and the president of Poland, Andrzej Duda, seemed to play such a role). Supposedly the decentralized and informal nature of the group means that the possible collapse of the political option showing enthusiasms for Central European cooperation in the leading state will not deprive the Initiative of the main catalyst for cooperation. The $3 \mathrm{rd}$ pillar that may secure cooperation and the achievement of goals set by the countries of Central Europe is the emerging level of institutionalized business partnerships. It should be understood both as the developing Three Seas Fund and the initiated common Stock Exchange index CEEplus.

1 TEN-T (Trans-European Transport Network) - is an instrument for coordination and ensuring coherence and complementarity of infrastructure investments. As a result of the revision of the guidelines for the TEN-T network, completed in 2013, its new layout was established in the territory of the EU Member States. That system comprises the core network, which is the basis for the development of the transport network on which Union action is to focus, in particular cross-border sections, missing links, multimodal connections and key bottlenecks, and a comprehensive network ensuring accessibility and connectivity for all regions of the Union.

In 2014, the implementation of TEN-T in the previously known form was completed and it was replaced by an institution called the Innovation and Networks Executive Agency, which took over the coordination of former TEN-T projects. The author will, however, use the concept of TEN-T as a model of the target shape of communication and energy roads, which will be better internalized in general perception.

Source of the definition: Ministry of Infrastructure of the Republic of Poland, Trans-European Transport Network - TEN-T, www.gov.pl/web/infrastruktura/transeuropejska-siec-transportowa-ten-t, 19.06.2020. 
As a result of the synthesis of the assumptions, the author puts forward a hypothesis that the mechanisms (pillars) ensuring the durability and effectiveness of the Three Seas Initiative in achieving the set goals can be defined in three categories:

1) integrating Three Seas goals into the framework of EU strategy programmes;

2) maintaining the informal and decentralized nature of the Initiative;

3) development of mutual business and economic cooperation that will strengthen multilateral economic ties between countries of 3SI.

The following research questions were posed to verify the hypothesis:

1) What challenges does Europe face nowadays?

2) How do European countries cope with the current challenges?

3) What is the nature of the Three Seas Initiative, and how does it work?

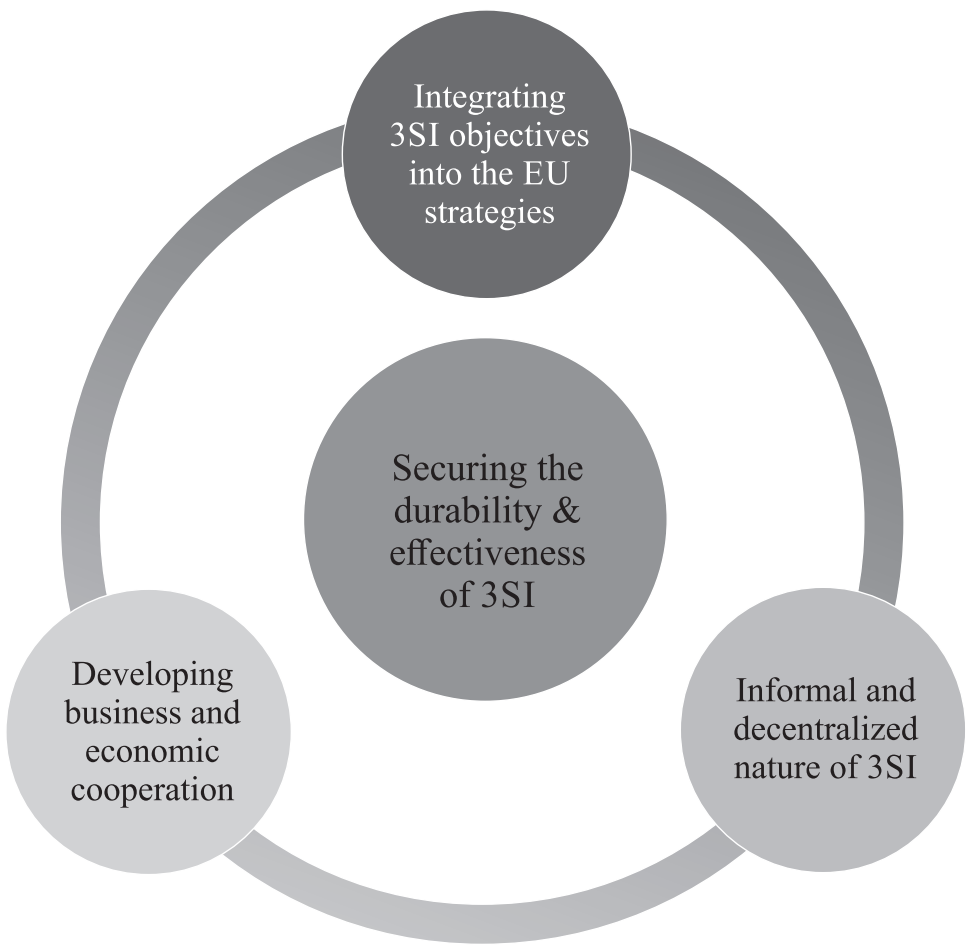

Graph 1. The system for securing the durability and effectiveness of Three Seas Initiative - diagram

Source: Own study. 
4) How do the goals of the Three Seas Initiative fit into the strategic activities of the European Union? How does this determine the effectiveness and durability of the $3 \mathrm{SI}$ ?

5) How is the 3 SI functioning organized? Does this translate into the attractiveness of this format for its participants?

6) Does 3SI have a commercial dimension, and can it be independent of changes in the political climate?

7) Are the proposed security mechanisms complementary to each other? If so, what effects are they achievable with?

To verify the hypothesis regarding security mechanisms, an analysis of existing data will be carried out, which will consist of system analysis and elements of strategy analysis.

\section{Contemporary Europe and embedding the three seas in euro-atlantic structures}

Today's Europe is torn by many crises, but it seems to be one of the most attractive places to live in the world (John, Layard, Sachs, De Neve, 2020). However, it is noted that Europe's current challenges are the size of and scope unheard of since the end of the Cold War. These are threats located on different levels, for example, 1) the threat of a restrictive US customs policy toward the EU, 2) economic instability in the southern countries of the continent, 3) transformation of Europe into a field of American-Chinese rivalry, 4) weakening of the common market and the political potential of the EU after Brexit, 5) unresolved and developing immigration crisis resulting in an influx of unassimilating cultures ${ }^{2}$, 6) unresolved military conflict in the Ukrainian Donbas and revisionist actions by the Russian Federation. The potential economic crisis which may result from the consequences of the COVID-19 pandemic remains a separate issue, but according to the author, it is too early to predict this impact in the context of this research problem.

In this context, it should be stated that threats to the European order are not a closed set. However, they illustrate the multidimensionality

2 The concept of assimilation should be understood as the process of adapting immigrants to the norms of social life in the host country. In the context of the problem outlined, the key is the first stage of assimilation, referred to as acculturation - the minority adopting the behavior patterns of the host community (adapting to the requirements of the applicable system). 
of the challenges for the European Union and NATO. Attention should also be paid to the relative softness of the economies of the EU countries and of the community itself. It means that its economic susceptibility to changes in world trade is higher than that of China, Brazil, or the Russian Federation (Lorek, 2019, p. 175). Therefore, the risks associated with the broader economy will affect the EU to a different extent across regions due to their specificities and possible economic specialization.

Regarding the immigration threats, an average observer of European life will notice that in this case, there is a clear division of the EU into the eastern and western parts. The first one clearly shows that it does not want to deal with the problem in its territory but at its origin. At the same time, it should be emphasized that western EU countries are destinations on the migration roads because they provide a higher standard of social welfare and at the same time are more crowded with minorities already living in them. Thus, the immigration crisis causes, inter alia, tensions in two areas: economic (as a burden on welfare systems (Stefańska, 2008, pp. 142-147)) and cultural (as an influx of culturally alien masses (Lorek, 2019, p. 175)). It also means an increase in the potential terrorist threat, which is its indirect effect. It is worth underlining that the European Union changed its perspective after the American and coalition evacuation from Afghanistan in 2021.

Another problem of the EU is the economic situation of southern European countries. Firstly, the problems of Greece, Italy, and Spain as euro area countries may have economic consequences for it which will probably be difficult to overcome due to the scale and power of influence. Moreover, the first two countries are burdened with the issue of immigration (described in the previous paragraph) because they are so-called "transfer states". On the other hand, an additional burden for the economies of Italy and Spain is the cost associated with the fight against COVID-19 due to the relatively large impact of the epidemic on how these entities function. The economic perturbations that have been going on in the South for over a decade determine the internal situation in these countries. Greece was forced to lower pensions, and in 2019 Spain passed a motion of no-confidence in the Prime Minister for the first time since the dictatorship of Francisco Franco. In Italy, on the other hand, radical political movements fueled by rising unemployment are gaining momentum (Lorek, 2019, p. 176). Therefore, it is difficult to talk about the optimistic prospects for stabilizing the internal situation of the EU Member States in the south of the continent and consequently about their positive impact on the euro area. 
The eastern part of Europe is just beyond the borders of the EU - also those do not present optimistic premises for a vision of a positive international situation or a general sense of security on the continent. In 2014, the Russian Federation annexed Ukrainian Crimea and launched military operations in eastern Ukraine (Donbas region), which raised particular concerns in the so-called Bucharest Nine - EU countries that are also on the eastern flank of the North Atlantic Alliance (and also members of the 3SI). Russia's actions are not without reason referred to as a revisionist policy around the former USSR. In addition, also Lukashenka's regime in Belarus is dangerous for Europe's eastern borders because Belarus is providing a hybrid war against the EU. As said by Manfred Weber, leader of the major European Parliament faction, "The ongoing attack on the EU border by the dictator Lukashenka is a strategic foreign policy challenge for the whole of Europe" (Defence24, 2021).

Therefore, it is clear that both the EU and NATO are in an unfavorable and unprecedented position. The turbulent borders of the Old Continent, unstable economic systems, the radicalization of socio-political sentiment, internal problems, and an epidemic are phenomena that both organizations cannot ignore. At the same time, many countries undertake actions on their own to overcome crises or cooperate in smaller groups (Baziur, 2018, p. 25). In response to some of the characterized challenges (Instytut in.Europa, 2020), in 2015, the Three Seas Initiative was founded (although it is formally referred to as 2016 when its first summit took place).

A common mistake, recurring especially in journalism, is equating the interwar concept of the Intermarium with the Three Seas Initiative (Intermarium vs. Trimarium). When geographical circumstances suggest such an association, it should be remembered that the 3SI describes itself as a "pragmatic internal EU initiative". Its main goals focus on economic issues, infrastructure, energy, logistics, and digitalization. Therefore, this scope can be interpreted as a project initiative at a cooperation forum rather than an international sub-organization (Sienkiewicz, 2016, p. 142). The Visegrad Group can be considered the nucleus of cooperation in 3SI as a kind of permanent community within the initiative - but this is somewhat due to the longer period of foul for cooperation or such a willingness to perceive Visegrad countries. However, other countries such as Croatia, Romania, and Estonia also have a noticeable influence on cooperation and actively influence on the Three Seas Initiative (Lorek, 2019, pp. 180-187; Orzelska-Stączek, Ukielski, 2020, pp. 80-85), which seems to contradict that phase is about the Visegrad core of the Three Seas Initiative. 
In the context of defining the Initiative, it is worth mentioning a fragment of the article by Marcin Sienkiewicz: "The concept of the Three Seas in general assumes the activation of Polish policy toward the countries of the region whose borders are roughly determined by the shores of the three seas: Adriatic Baltic and Black for the purpose of their political and economic consolidation. This concept is not intended to create a formal organizational framework that would compete with the European Union and the North Atlantic alliance. As a part of this project, the Polish side formulates proposals for the development of cooperation and building a community of interest in the region in the political economic and security area"3 (Sienkiewicz, 2016, p. 142). The concept of cooperation is also illustrated in the graphic below:
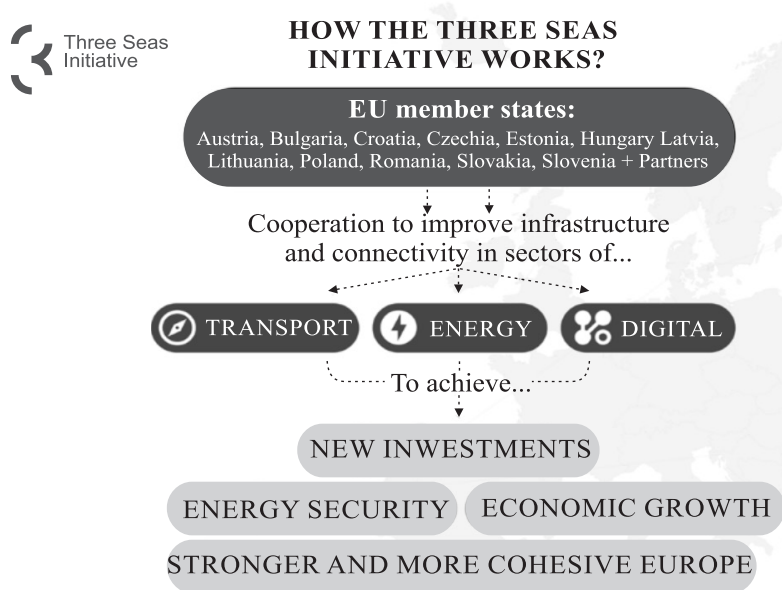

Graph 2. Diagram illustrating the operation of the Three Seas Initiative

Source: Three Seas Initiative, www.3seas.eu, 14.09.2020.

${ }^{3}$ Author's own translation. Original citation below:

"Koncepcja Trójmorza, najogólniej rzecz ujmując, zakłada zaktywizowanie polskiej polityki wobec państw regionu, którego granice w przybliżeniu wyznaczone są przez wybrzeża trzech mórz: Adriatyckiego, Bałtyckiego i Czarnego, w celu ich politycznej i gospodarczej konsolidacji. Koncepcja ta nie zmierza do tworzenia formalnych ram organizacyjnych, konkurencyjnych wobec Unii Europejskiej (UE) i Sojuszu Północnoatlantyckiego (NATO). W ramach tego projektu formułowane są natomiast przez stronę polską propozycje rozwoju współpracy i budowy wspólnoty interesów regionu w obszarze politycznym, gospodarczym i bezpieczeństwa”. 
Translating the infographic's content, it should be indicated that the largest field includes the EU member states that created the Three Seas initiative. Collaboration for improving infrastructure and connectivity in the transport, energy, and digital sectors is defined below (displayed in the boxes in the middle of the graphic). Then cause and effect sequence is indicated in which cooperation in these dimensions translates into the achievement of new investments, energy security, economic growth, and a stronger and more cohesive Europe ("pyramid" of fields at the bottom of the graphic). Bearing in mind the words of M. Sienkiewicz and general characteristics of initiative, it can be staked with a certain degree of certainty that the mutual suffering for countries within their initiative may allow implementation of their goals both particulars and team. At the same time, this form of cooperation allows for the comprehensive and innovation-oriented development of each of the partnership members. While the key role of the decentralization and the formalized nature of the initiative will be discussed in the following sections, at this point, it should be noted that Poland is a specific geographic bond for the project because it is the only country spatially connecting the Baltic countries with it southern partners. Therefore, from the economic and infrastructural point of view, each transcontinental initiative with a North-South orientation will be desired by the Republic of Poland and may contribute to various positive economic stimuli.

\section{Analyzes of the $\mathbf{1}^{\text {st }}$ pillar of durability and effectiveness security - inclusion of 3SI objectives in the framework of EU strategic programmes}

The undoubted success of the implementers of 3SI in 2015-2020 was the reversal of the perception of this project in the European Union from skeptical, potentially competitive, and even sabotage to European integration to perception as an initiative complementary to the community objectives. As Paweł Ukielski noted, "one of the first proofs of real thinking in terms of EU categories is the fact that Ukraine does not participate in the initiative (despite the enormous interest declared in the various forums) and that Austria showing still far-reaching registrant, was invited. Thus, the Three Seas Initiative maintains an intra-EU character and tries to break the dichotomy between old and new members of 
the Union"4 (Ukielski, 2018, pp. 48-49). Therefore, it can be concluded that 3 SI will be partially regarded as "executive" agenda of community policies in the so-called the new EU.

The same researcher points out among the evidence for the consistency of the Initiative with the EU that the objectives of the initiative are in line with the EU's core strategy documents: that 2030 energy strategy, digital single market, and road map of the single European transport area (Ukielski, 2018, p. 49). Undoubtedly, the objectives of 3SI are the same as the EU plans, because already in the Initiative project in 2015, the signatories of the cooperation declared among their intentions to build synergy to obtain support for projects in the energy, transport, digital, communication, and economic sectors.

One of the guests at the $3 \mathrm{Si}$ summit in Brda, near Ljubljana, was the head of the European Commission, Jean Claude Juncker. He noted that in 2004-2020 the 3SI countries received 60 billion euros from structural funds. The draft budget for 2021-2027 amounted to 24.3 billion euros, especially for road infrastructure (Bodalska, 2019). The literature mentions several infrastructure projects that express the common interests of the initiative. However, to explain the first pillar of the security system, which is the focus of this article, the outer will only use communication designs. However, it should be noted that a similar role may also be played by other projects, for example, those related to energy security.

Infrastructure projects are investments that in the long run may translate not only into economic growth of the regional countries but also into the pan-European standard of transport energy services and even into a change in spatial behavior (Wronkowski, 2019, pp. 188-190) or a sense of subjective well-being (Górny, 2018, pp. 58-61). Tangible infrastructure is one of the two dimensions of EU policy implementation (European Regional Development Fund and European Social Fund). In the 3SI area, 48 projects were distinguished in 2018 for a broader range of the EU investment framework (Three Seas Initiative, 2020). Transcon-

${ }^{4}$ Author's own translation. Original citation below:

"Za jeden z pierwszych dowodów na realne myślenie kategoriami unijnymi należy przyjąć fakt, że w Inicjatywie udziału (mimo olbrzymiego zainteresowania deklarowanego na różnych forach) nie bierze Ukraina, a zaproszona została, wykazująca wciąż daleko idącą wstrzemięźliwość, Austria. W ten sposób Trójmorze zachowuje wewnątrzunijny charakter, a także stara się przełamać dychotomię między starymi a nowymi członkami Unii”. 
tinental projects with a meridional orientation are among the key ones because a cursory analysis of the motorway or rail map of Europe allows us to identify a disproportionately poor number of them in relation to the west-east routes. In the author's opinion, for example, 3SI routes should be indicated, such as Via Carpathia (from Klaipeda in Lithuania to the Saloniki in Greece, which has numerous integrated arms), Via Baltica (from Poland to Estonia, complementing Via Carpathia), Rail Baltica, and Amber Rail Freight Corridor. Selected infrastructure projects are presented in the graphics - picture's 1-4.

An important action taken by the 3SI is the implementation of infrastructure projects into the Trans-European Transport Network (TEN-T), which provides them with funding at the EU strategic level and thus brings them closer to achieving these ambitious goals from a Central European perspective. In the era of EU countries' efforts to distribute funds for the next financial perspective, there is a chance to embed the ambitious projects in institutionalized programmes that will become the guarantors of their implementation - this time, however, under the Innovation and Networks Executive Agency, which is responsible for EU-wide planning and implementation of communication investments (Innovation and Networks Executive Agency, 2020). However, it should be noted that the projects do not cover the catalog of strategic investments for the Three Seas Initiative (energy projects, for example, were not indicated (Baziur, 2020, pp. 144-147)).

Undoubtedly, ensuring investments and financial instruments for the key infrastructure aspirations of the region's countries in the European Union's policy will transform into the durability and effectiveness of the Three Seas Initiative. It is worth noting that this is a phenomenon that at the same time ensures the achievement of the goals set by 3SI, but it cannot be ruled out that 3SI will evolve, develop, and expand its activities. Assuming that the initiative's infrastructure projects are embedded in higher, institutionalized structures, it can be argued that they will play a stabilizing role for 3SI, irrespective of possible political disruptions in various Central European states. At the same time, it is difficult to forecast further goals that the Initiative could set itself. However, it is worth remembering in this context that the first European communities, such as the European Coal and Steel Community, were born from, inter alia, out of the need for economic cooperation and strengthening the region's political importance. Therefore, 3SI can also be seen as a canvas for further directions of strategic development of the associated countries and as a tool for implementing these plans. 


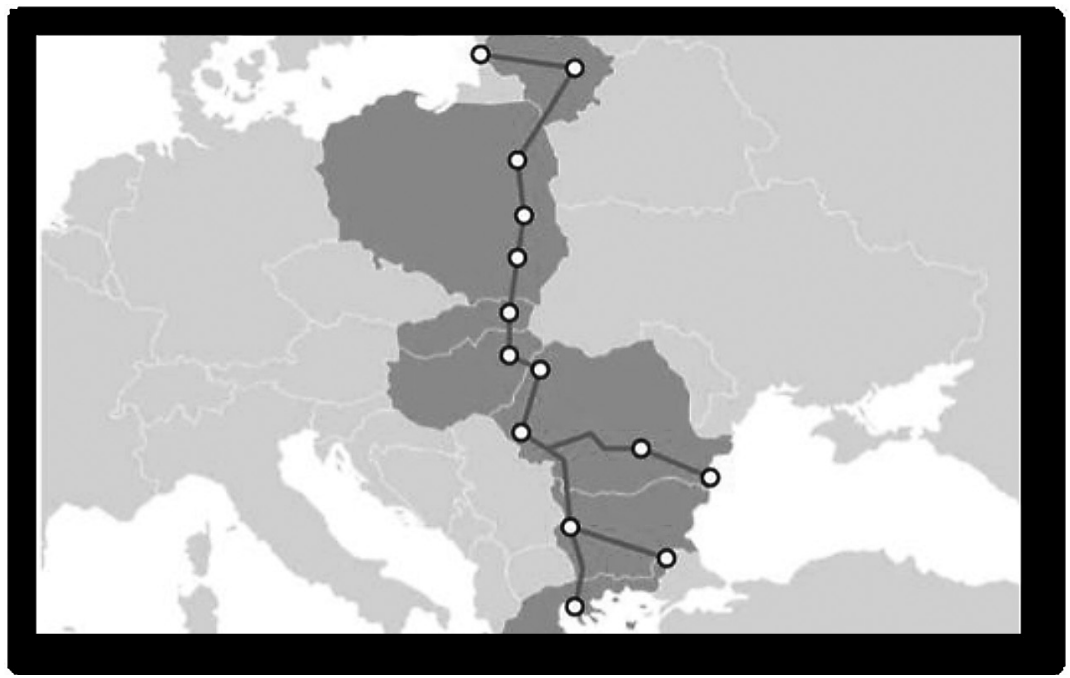

Picture 1. Via Carpatia according to Łańcut Declaration III

Source: K. Hennig, Inicjatywa Trójmorza jako inicjatywa rozwoju infrastrukturalnego, www.merytoryczny.pl, 14.09.2020.

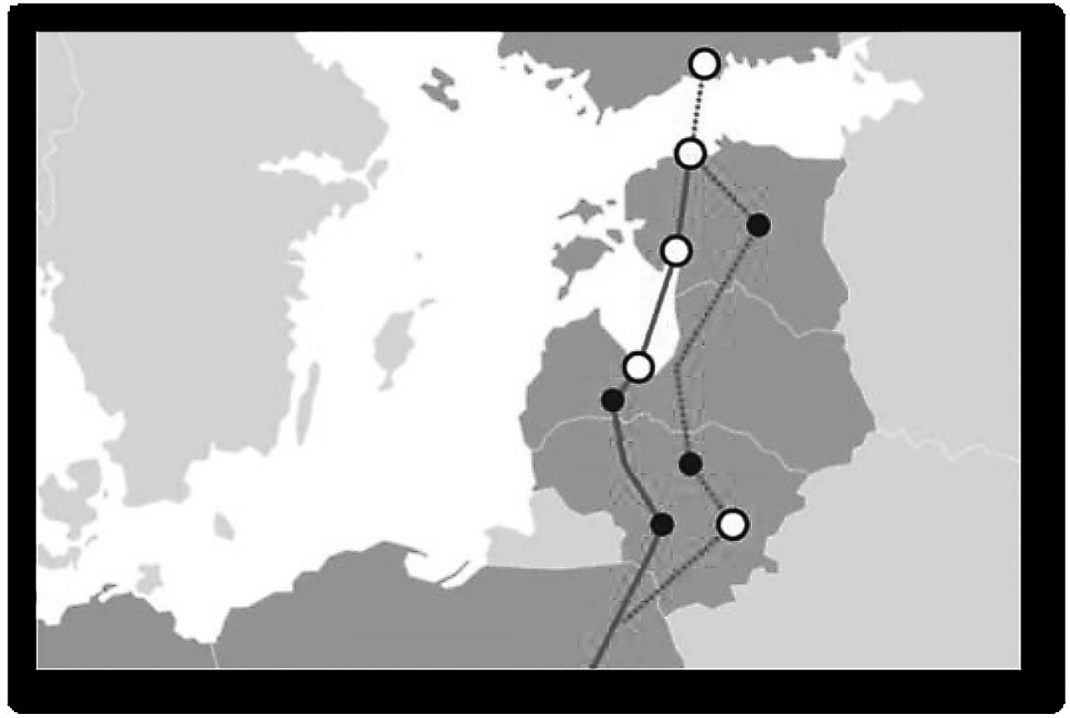

Picture 2. Via Baltica

Source: K. Hennig, Inicjatywa Trójmorza jako inicjatywa rozwoju infrastrukturalnego, www.merytoryczny.pl, 14.09.2020. 


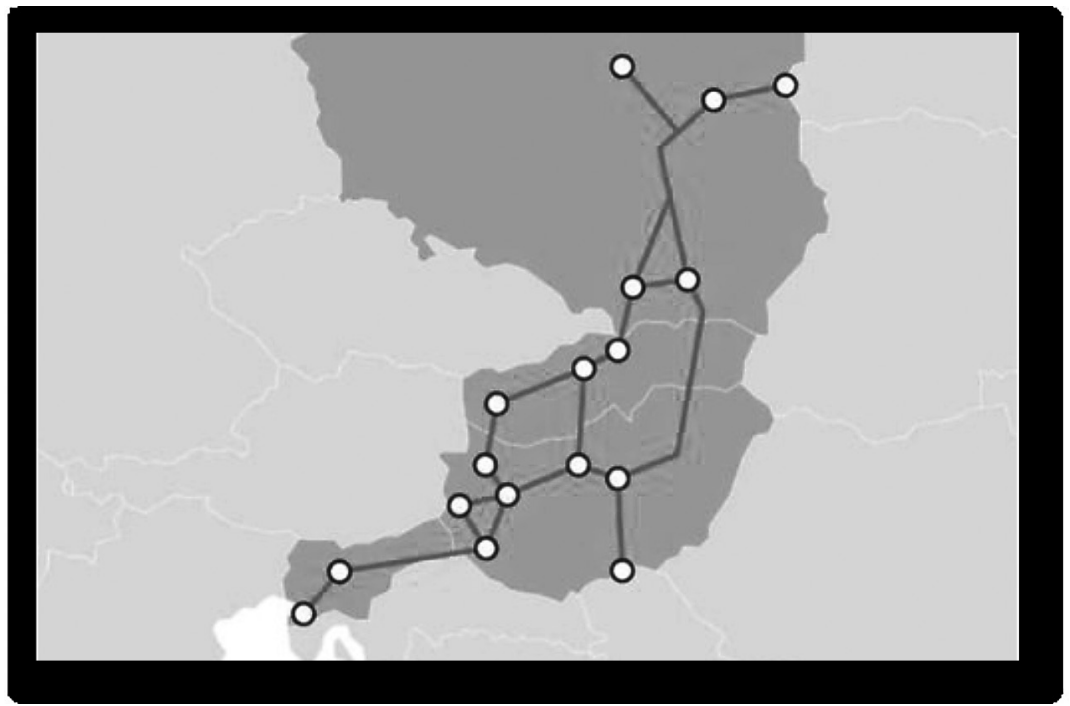

Picture 3. Amber Rail Freight Corridor

Source: K. Hennig, Inicjatywa Trójmorza jako inicjatywa rozwoju infrastrukturalnego, www.merytoryczny.pl, 14.09.2020.

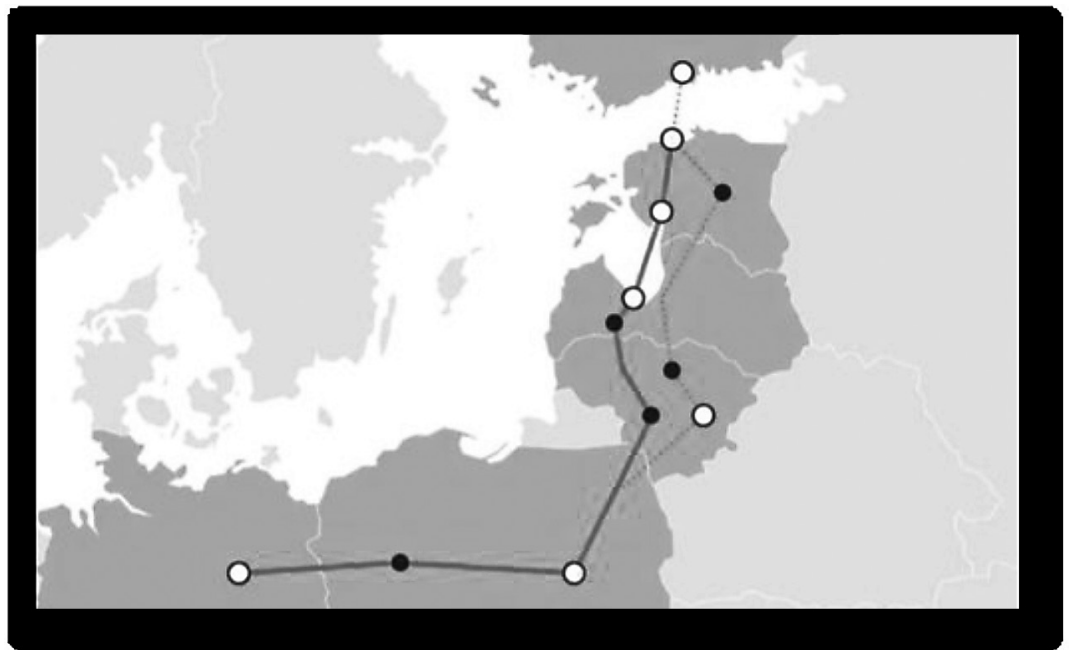

Picture 4. Rail Baltica

Source: K. Hennig, Inicjatywa Trójmorza jako inicjatywa rozwoju infrastrukturalnego, www.merytoryczny.pl, 14.09.2020. 


\section{Analysis of the $2^{\text {nd }}$ pillar of durability and effectiveness security - de-formalized and decentralized nature of 3SI}

For Central European countries, located directly between two powerful political and economic influence centers, maintaining decision-making independence on the political and executive levels seems to be the key task. The cooperation platform, which is 3SI, seems to be a solution not so much a compromise, but desirable by these entities - both from the perspective of small Baltic countries (the Republic of Estonia, the Republic of Latvia, the Republic of Lithuania), inland (Hungary, the Czech Republic, and the Slovak Republic), or southern (the Republic of Croatia, Republic of Slovenia, Romania and the Republic of Bulgaria). The idea of a partnership of associated states is expressed precisely in the form of cooperation - as Agnieszka Orzelska-Stączek (2019, pp. 135-136) pointed out - referring to the theory of realism in international relations. 3SI is not an international organization. It does not have a document constituting cooperation (apart from the founding declaration, which, however, does not have a normative function). The only written traces of cooperation are the declarations announced after each of the group's summits. In the absence of institutionalized structures and rigid rules, states are free to enter and exit individual projects. Why, in the face of this institutional weakness and the theses of this article, should it be considered an asset?

Most of the Initiative countries are small entities. In the case of organizations such as the EU, their voice is also proportionately weaker, precisely because of the institutionalized forms of making binding decisions. Deformalizing the Three Seas Initiative may be an advantage in building the project's attractiveness for its members. It is worth noting that the hosts of the 3SI summits have been Croatia, Poland, Romania, and Slovenia, and in 2020 it will be Estonia. Three of these countries can be described as small compared to other members of the EU. Smaller countries are more willing to undertake international cooperation and participate in projects of this nature with greater influence on decisions made and the possibility of obtaining a greater range of information that interests them (Orzelska-Stączek, 2019, p. 148).

De-formalizing cooperation is not the only dimension of the decentralization pillar. Also, decentralization in the strict sense may appear as a form of securing the sustainability and effectiveness of the project. When analyzing this issue, the perspective of relatively weaker countries in the entire EU should be adopted - the lack of a formal seat of the Initia- 
tive means that its professional structures will not develop. The "officials" of the Three Seas Initiative are officials working on individual projects or organizing meetings during summits. As a result, there is no suspicion of appropriation of 3SI by one, tandem, or several countries ${ }^{5}$. The only quasi-formal 3SI units are secretariats, which are created ad hoc to organize individual summits.

The Three Seas Initiative as a platform for cooperation between executive authorities and business in its current form has a soft and seemingly unstable nature. Each of the countries may terminate the cooperation at any time, both sectorally and as a whole. It is due to the non-formal nature of the group. In this context, the key to maintaining the sustainability of the $3 \mathrm{SI}$ is to build the attractiveness of the project so that it is beneficial to every major policy option in all partner countries. It proves the coherence of the second pillar of sustainability and effectiveness of the Initiative with the first one - because the infrastructural values will constitute an attractive benefit for the universally understood political class of the Three Seas Initiative. However, the hitherto short history of 3SI proves that despite political changes in individual countries (e.g., in Slovakia or Croatia), these entities do not drift away from Central European cooperation. At this point, one can also see the civilization vector of the impact of 3SI as a potential mechanism for creating one's own Central European culture and political thought, based on a loose and voluntary union of states and the principle of partnership and solidarity.

\section{Analysis of the $3^{\text {rd }}$ pillar of durability and effectiveness security - development of multilateral business and economic cooperation of 3SI countries}

The third pillar securing the durability and effectiveness of the Three Seas Initiative is the development of mutual business and economic cooperation. On the surface, it may appear to be related to the first pillar, which was described earlier. However, it should be clarified that the third aspect relates to cooperation at the level of entrepreneurs and business, instead of transcontinental projects created and coordinated by states or the EU.

5 This accusation is relatively often formulated against the way the EU administration functions as a tool for the realization of German-French interests. 
Starting in 2018, economic summits are being held at the same time as the 3SI summit attended by the highest representatives of states. The result of the work was the Three Seas Fund established in 2019, founded by Bank Gospodarstwa Krajowego (Poland) and EximBank (Romania). In March 2020, the representatives of the Fund declared that they had already managed to collect an amount of EUR 520 million (Three Seas Investment Fund, 2020), which is to be allocated to investments in the infrastructure of partner countries and to leveling the differences with Western Europe. In theory, this is a different mechanism to achieve goals, to which the first pillar also applies (embedding strategic projects within the framework of EU policies). However, private investors are also to be invited to the Three Seas Fund. Undoubtedly, it may contribute to the qualitative improvement of the financed projects and their economic profitability.

An important, pro-quality aspect of the Fund is entrusting management consultancy to a private, professional organization - Amber Infrastructure Group (Amber Infrastructure Group, 2020). The United States also declared significant financial support at the beginning of 2020, but because of the COVID-19 pandemic, it is difficult to forecast the real future of this declaration ( $\$ 1$ billion in funding for 3SI). The Supervisory Board of the Fund includes representatives of the 3SI countries: Poland, Latvia, the Czech Republic, Romania, and Estonia (Three Seas Initiative Fund, 2020). The nature of this project, similar in its assumptions to the public-private partnership known in Europe, may be related to its resistance to possible political changes within 3SI and thus will translate into strengthening the durability and effectiveness of achieving the goals set by the Three Seas Initiative. Interesting, however, is the lack of a single location for the seat of the Fund again. "The Three Seas Fund will not have a permanent seat, as the meetings of the board of directors are to be held rotating in the capitals of 12 partner countries. From the management point of view, it is probably not the optimal model, but it allows to avoid discussions where to place the headquarters" (Twaróg, 2018). It is another confirmation of the Initiative's decentralization, another premise for the coherence of the 3SI security system, and potential proof of the implementation of the partnership principle.

${ }^{6}$ Author's own translation. Original citation below:

"Fundusz Trójmorza nie będzie mieć stałej siedziby, gdyż spotkania rady dyrektorów mają odbywać się rotacyjnie w stolicach 12 państw partnerów. Z punktu widzenia zarządzania nie jest to pewnie optymalny model, pozwala natomiast uniknąć dyskusji, gdzie umieścić centralę". 
Another project that emerged within the Three Seas Initiative is the CEEplus stock exchange index initiation in 2019 (Forsal, 2019). Its publication is based on the portfolio of the largest and most liquid companies from Croatia, the Czech Republic, Poland, Romania, Slovakia, Slovenia, and Hungary (Giełda Papierów Wartościowych, 2020). It is difficult to assess the significance and effectiveness of this instrument at the moment, as it is relatively young in the context of the entire 3SI. However, it is worth noting that this action was only initiated at the political level and entrusted to the market and economic processes. It may transform into the generation of synergies in economic cooperation, but it is only a potential scenario that should be monitored.

\section{Conclusion and potential recommendations}

Previous studies on the Three Seas Initiative usually do not holistically address the sustainability and effectiveness of this project. However, the author is aware that the presented considerations can only contribute to further research on the issue in question and deeper analyses. However, it should be acknowledged that in order to ensure a longer perspective of the duration of 3SI and the implementation of an ambitious plan to bridge the infrastructural (or more broadly speaking, civilization-related) differences between Central and Western Europe, scientists should focus on researching and diagnosing tools that will ensure this durability.

The conducted analytical and evidence chain allows to confirm the assumptions made at the beginning, according to which, in order to properly secure the effectiveness of 3SI, cooperation should be based on 1) inclusion of the Initiative's objectives in the framework of EU strategic programmes, 2) maintaining the decentralized and informal nature of the project, 3 ) developing multilateral business cooperation and economic development of Central European countries. The key premises that constitute the strength of the indicated pillars of the 3SI security system are the use of the EU financial and strategic framework to achieve the objectives of the Initiative, maintaining its resistance to changes in the political mood of the associated countries (which prevents members from permanently breaking out of cooperation), stimulating and supporting professional instruments economic cooperation and building economic ties along the North-South axis.

In addition, important conclusions drawn from the study allow us to indicate Poland's bridging, "keystone" nature in 3SI, which spontaneous- 
ly plays a role that integrates the north with the south of the Three Seas Initiative. This role should be used in a way that can generate maximum economic benefits, and at the same time, will strengthen the potential of the entire Initiative. Another observation is the potential unawareness of the associated countries of the civilizational role that 3SI may play and the possible seediness of broader cooperation in the future. Effective implementation of the assumed projects will undoubtedly impact further integration and increasing the willingness to cooperate, which will translate into the region, and each country separately.

It is impossible to assess whether the outlined security system was created consciously, designed by the leaders of Central Europe, or whether it is the result of the spontaneous crystallization of forms of cooperation. During the studies, no information was found that would clearly indicate that the Initiative was constructed in this way. At the same time, it is thought that the characteristic feature of the countries of the region in the Three Seas region has long been integration in a spontaneous, natural, voluntary, and bottom-up manner. Perhaps in this somewhat idealistic or utopian thought, one should look for civilization opportunities for Central Europe.

\section{Bibliography}

Amber Infrastructure Fund (2020), Three Seas Investment Fund, www.amberinfrastructure.com, 26.07.2020.

Baziur G. (2018), Trójmorze jako koncepcja bezpieczeństwa i rozwoju ekonomicznego Europy Wschodniej, "Przegląd Geopolityczny", vol. 23.

Bodalska B. (2019), Inicjatywa Trójmorza zdynamizuje swoje działania, "Euractiv", www.euractiv.pl, 14.09.2020.

Defence24 (2021), Unijny ptot na granicy z Biatorusią?, www.defence24.pl, 26.09.2021.

Forsal (2019), Powstanie indeks Trójmorza. GPW I 6 giełd region szykują CEEplus, "Forsal", www.forsal.pl, 25.07.2020.

Giełda Papierów Wartościowych (2020), Karta indeksu CEEplus, www.gpebenchmark.pl, 25.07.2020.

Górny M. (2018), The importance of work in human life and development. The consequences of unemployment, "Refleksje. Czasopismo naukowe studentów i doktorantów WNPiD UAM", vol. 18.

Hennig K. (2019), Inicjatywa Trójmorza jako inicjatywa rozwoju infrastrukturalnego, "Merytoryczny", www.merytoryczny.pl,15.06.2020. 
Innovation and Networks Executive Agency (2020), Responsibilities, www. ec.europa.eu/info/departments/innovation-and-networks-executive-agency_ en, 14.09.2020.

Instytut in.Europa (2020), Trójmorze wzmocni potencjał Unii Europejskiej, "Wskaźnik zdolności produkcyjnych państw 2017”, www.index.ineuropa.pl, 12.07.2020.

John F., Layard R., Sachs J., de Neve J.-E. (2020), World Happiness Report 2020, www.worldhappiness.report, 19.06.2020.

Lach Z. (2020), Dylematy rozwoju i bezpieczeństwa państw Europy Środkowo-Wschodniej, "Przegląd Geopolityczny”, vol. 31, www.przeglad.org, 14.09.2020.

Lorek A. M. (2020), Konferencja - prawo a polityka, “Artur M. Lorek - politologia \& administracja", www.armalorek.wordpress.com, 28.07.2020.

Lorek A. M. (2019), Polska dyplomacja na "osi y" - restytuowanie sentymentów czy szukanie nowego paradygmatu?, in: Polska na arenie międzynarodowej. Wygrany rozwój czy zmarnowane szanse?, ed. A. Drozdek, Wydawnictwo Think\&Make, Warszawa.

Ministry of Infrastructure of the Republic of Poland (2020), Trans-European Transport Network - TEN-T, www.gov.pl/web/infrastruktura, 19.06.2020.

Orzelska-Stączek A. (2019), Inicjatywa Trójmorza w świetle teorii realizmu. Polityczne aspekty nowej formy wspótpracy dwunastu państw, "Sprawy Międzynarodowe", vol. 71.

Orzelska-Stączek A., Ukielski P. (2020), Inicjatywa Trójmorza z perspektywy jej uczestników, Instytut Nauk Politycznych PAN, Warszawa.

Sienkiewicz M. (2016), Koncepcja “Trójmorza” w polskiej polityce zagranicznej po 2015 r., in: Dyplomacja i bezpieczeństwo. Między wojna i dyplomacją. Polityka zagraniczna Polski w świetle wyzwań na arenie międzynarodowej, vol. 1(4), ed. M. Mróz, Instytut Studiów Międzynarodowych UWr, Wrocław.

Stefańska R. (2008), Między multikulturalizmem a asymilacją? Polityki integracyjne w Europie, in: Problemy integracji imigrantów. Koncepcje, badania, polity$k i$, ed. A. Dąbrowska-Korzus, Wydawnictwa Uniwersytetu Warszawskiego, Warszawa.

Three Seas Initiative (2020), Progress Report, www.3seas.eu, 20.07.2020.

Three Seas Initiative Investment Fund (2020), E520m Initial Commitments into 3SIIF and appointment of Amber Infrastructure as Exclusive Adviser, www.3siif. eu, 20.07.2020.

Twaróg E. (2018), Trójmorze będzie wspólnie budować, "Puls Biznesu”, www.pb.pl, 25.07.2020.

Ukielski P. (2018), Inicjatywa Trójmorza w polskiej polityce zagranicznej, "Studia Europejskie", vol. 2.

Wronkowski A. (2019), Teoria ośrodków zachowania - propozycja zastosowania $w$ badaniach przestrzeni publicznych, in: Współczesne problemy i kierunki badawcze w geografi - tom 7, eds. K. Anielska, Ł. Fiedeń, Instytut Geografii i Gospodarki Przestrzennej UJ, Kraków. 


\section{System zabezpieczeń trwałości i skuteczności Inicjatywy Trójmorza}

\section{Streszczenie}

Celem niniejszego artykułu jest ocena systemu zabezpieczeń dla trwałości i skuteczności Inicjatywy Trójmorza jako nieformalnego bloku państw Europy Środkowej. Autor diagnozuje zbiór elementów stanowiących potencjalne „bezpieczniki” dla realizacji założonych przez 3SI celów: osadzenie priorytetów Inicjatywy w ramach strategicznych programów UE, odformalizowanie i zdecentralizowanie współpracy oraz rozwijanie wzajemnej współpracy biznesowej i gospodarczej. Analiza systemu zabezpieczeń została osadzona w kontekście współczesnych wyzwań, z jakimi mierzy się Europa. Celem weryfikacji problemu mechanizmów zabezpieczenia przeprowadzono analizę danych zastanych, na co składały się analiza systemowa (polityczna) oraz elementy analizy strategicznej. Rezultatem pracy badawczej było określenie wzajemnego oddziaływania na siebie i warunkowania poszczególnych filarów trwałości i skuteczności 3SI, a tym samym przeprowadzono dowodzenie na rzecz zasadności uznania trzech określonych wcześniej aspektów za kluczowe dla efektywnego działania Trójmorza.

Słowa kluczowe: Trójmorze, Inicjatywa Trójmorza, trwałość, skuteczność 
